\title{
EUROPEJSKI NAKAZ DOCHODZENIOWY - PRZEŁOM W DZIEDZINIE EUROPEJSKIEGO ŚCIGANIA KARNEGO?
}

\section{ISTOTA EUROPEJSKIEGO NAKAZU DOCHODZENIOWEGO}

Walka z dynamicznie rozwijającą się przestępczością transgraniczną, mimo intensywnych prac organów Unii Europejskiej, wciąż stanowi słaby punkt integracji w ramach byłego trzeciego filaru ${ }^{1}$. Otwarte granice sprzyjają bowiem nie tylko swobodnemu przepływowi osób, towarów, usług czy mienia, lecz także rozwojowi przestępczości o międzynarodowym wymiarze. Państwa członkowskie samodzielnie nie są w stanie sprostać potrzebom związanym ze ściganiem na terenie całej Unii Europejskiej, stąd konieczność utworzenia jednolitych w całej Wspólnocie instrumentów współpracy w sprawach karnych. Policja i organy sądowe winny bowiem dysponować skutecznymi metodami współdziałania, umożliwiającymi natychmiastową reakcję na popełnione przestępstwo, niezależnie od kraju, na terenie którego miało ono miejsce ${ }^{2}$.

Dotychczasowe (niezbyt skuteczne w praktyce) formy współpracy europejskiej w sprawach karnych sprowadzają się głównie do poniższych instrumentów:

a) Europejskiej konwencji o pomocy prawnej w sprawach karnych z 1959 r.,

b) Układu z Schengen z 1985 r.,

c) Protokołu do Konwencji o pomocy prawnej w sprawach karnych pomiędzy państwami członkowskimi Unii Europejskiej z 29 maja 2000 r.,

d) decyzji ramowej Rady nr 2008/978/WSiSW z 18 grudnia 2008 r. w sprawie europejskiego nakazu dowodowego dotyczącego przedmiotów, dokumentów i danych, które mają zostać wykorzystane w postępowaniach w sprawach karnych $^{3}$.

1 A. Lach, Zabezpieczenie dowodów i mienia na terytorium Unii Europejskiej, w: A. Górski (red.), Zwalczanie przestępczości w Unii Europejskiej, Warszawa 2006, s. 391-394.

2 D. Sayers, The European Investigation Order - Travelling without a „Roadmap”, CEPS Paper in Liberty and Security in Europe, 2011, http://aei.pitt.edu/32160/, s. 1 (dostęp: 1.02.2012).

${ }^{3}$ Istotą europejskiego nakazu dowodowego było stworzenie swobodnego przepływu przedmiotów, dokumentów i danych na terenie UE. Nakaz ten, choć w momencie uchwalania był instrumentem najdalej idącym w kwestii wzajemnego uznawania, wzbudzał wiele kontrowersji. Krytykowano głównie postępujące rozdrobnienie metod współpracy w europejskim ściganiu karnym. Fala sprzeciwu okazała się skuteczna - prace transpozycyjne w sprawie europejskiego nakazu dowodowego zostały wstrzymane, a europejski nakaz dowodowy został zastąpiony propozycją europejskiego nakazu dochodzeniowego. 
e) decyzji ramowej Rady UE (nr 2003/577/WSiSW) z 22 lipca 2003 r. w sprawie wykonywania w Unii Europejskiej postanowień o zabezpieczeniu mienia i środków dowodowych (tzw. freezing) ${ }^{4}$.

Wynikiem tak licznych metod współpracy, odnoszących się jedynie do poszczególnych działań, jest znaczne utrudnienie ścigania na terenie Unii Europejskiej. Uzyskanie przez policję lub organy sądowe dowodów znajdujących się na terenie innego państwa członkowskiego wymaga bowiem użycia skomplikowanej procedury, kompleksowej wiedzy na temat obowiązujących instrumentów i - niestety - nie gwarantuje zakończenia postępowania sukcesem. Dzieje się tak również ze względu na liczne podstawy odmowy pomocy oraz zbyt elastyczne terminy wykonania. Dlatego właśnie tworzenie prostych, klarownych i zarazem skutecznych metod współpracy między państwami członkowskimi w sprawach karnych stanowi obecnie jedno z podstawowych zadań Unii Europejskiej.

Efektem prac nad ujednoliceniem i usprawnieniem europejskiego ścigania karnego jest najnowszy instrument współpracy - europejski nakaz dochodzeniowy, zaproponowany przez 7 państw członkowskich ${ }^{5} 21$ maja 2010 r. i przyjęty przez Komisję Europejska 25 sierpnia 2011 r. Zgodnie z art. 1 Decyzji: „Europejski nakaz dochodzeniowy to orzeczenie sądowe, które właściwy organ jednego państwa członkowskiego (zwanego dalej »państwem wydającym «) wydaje, by w innym państwie członkowskim (zwanym dalej »państwem wykonujacym «) spowodować przeprowadzenie co najmniej jednej z określonych czynności dochodzeniowych służących zgromadzeniu materiału dowodowego w ramach postępowania, o którym mowa w art. 4"6. Instrument ten ma być przełomowy $\mathrm{w}$ dziedzinie ścigania transgranicznego w Unii Europejskiej, głównie ze względu na ujednolicenie procedury, skuteczność oraz elastyczność nakazu (,,single, efficient and flexible instrument”) ${ }^{7}$. Ponadto nakaz ten nie wprowadza żadnych ograniczeń w zakresie charakteru pozyskiwanych dowodów ${ }^{8}$, ale wprowadza restrykcyjne terminy wykonania oraz minimalne podstawy odmowy.

\footnotetext{
${ }^{4}$ J. R. Spencer, The Problems of Trans-Border Evidence and European Initiatives to Resolve Them, „Cambridge Yearbook of European Legal Studies” 9, 2007, s. 466-467.

${ }^{5}$ Belgię, Bułgarię, Estonię, Hiszpanię, Austrię, Słowenię i Szwecję.

${ }^{6}$ Council of the European Union, Proposal for a Directive of the European Parliament and the Council regarding the European Investigation Order in criminal matters, Brussels, 21 maja 2010 r., 2010/0817 (COD), polska wersja językowa na: http://www.europarl.europa.eu/meetdocs/2009_2014/ documents/cls/cons_cons\%282010\%2909288_/cons_cons\%282010\%2909288_pl.pdf (dostęp: 27.01.2012; dalej jako: Decyzja).

${ }^{7}$ Council of the European Union, Proposal for a Directive of the European Parliament and the Council regarding the European Investigation Order in criminal matters - Explanatory Memorandum, Brussels, 3 czerwca 2010 r., 2010/0817 (COD), http://register.consilium.europa.eu/pdf/en/10/st09/ st09288-ad01.en10.pdf, s. 2 (dostęp: 27.01.2012; dalej jako: Explanatory Memorandum).

${ }^{8}$ Zakres przedmiotowy został znacznie poszerzony w porównaniu z poprzednio ustanowionymi instrumentami. Freezing odnosił się bowiem jedynie do zatrzymania dowodów oraz zabezpieczenia mienia, natomiast europejski nakaz dowodowy wyłącznie do przedmiotów, dokumentów oraz danych.
} 


\section{WARUNKI I TRYB WYDANIA EUROPEJSKIEGO NAKAZU DOCHODZENIOWEGO}

Jedną $\mathrm{z}$ głównych zalet europejskiego nakazu dochodzeniowego jest jego uniwersalność - ograniczenia wydania nakazu są bowiem niewielkie ${ }^{9}$. Organ wydający powinien przed przystąpieniem do procedury określić, czy istnieje możliwość wydania nakazu

a) w toku danego postępowania,

b) w odniesieniu do wnioskowanej czynności dochodzeniowej.

Ad a) Rodzaje postępowań, w toku których istnieje możliwość wydania nakazu, określa art. 4 Decyzji. Należą do nich wszelkiego rodzaju postępowania karne toczące się w państwie wydającym, a także postępowania administracyjne, jeśli mogą w przyszłości skutkować wszczęciem postępowania, szczególnie karnego $\mathrm{w}$ danym państwie ${ }^{10}$.

Ad b) Zakres stosowania nakazu określony w art. 3 Decyzji jest, zdaniem jej twórców, podstawową zaletą tegoż instrumentu. Zapewnia bowiem spełnienie podstawowej funkcji - spójności oraz związanej z tym zwiększonej skuteczności ${ }^{11}$. Europejskiemu nakazowi dochodzeniowemu podlega bowiem każda czynność dochodzeniowa z wyjątkiem:

- czynności związanych z utworzeniem oraz działalnością zespołu dochodzeniowo-śledczego (określonych w art. 13 Konwencji o pomocy prawnej w sprawach karnych pomiędzy państwami członkowskimi Unii Europejskiej z 29 maja 2000 r. oraz w decyzji ramowej Rady nr 2002/465/WSiSW z 13 czerwca 2002 r. w sprawie wspólnych zespołów dochodzeniowo-śledczych),

- przechwytywania przekazów telekomunikacyjnych, określonych w tytule III Konwencji o pomocy prawnej w sprawach karnych pomiędzy państwami członkowskimi Unii Europejskiej z 29 maja 2000 r.

Ograniczenia wydania nakazu są więc niewielkie, zredukowane do niezbędnego minimum wynikającego $\mathrm{z}$ innych międzynarodowych aktów normatywnych, regulujacych kwestie współpracy $\mathrm{w}$ sprawach karnych między państwami członkowskimi. Zdaniem Komisji Europejskiej takie rozwiąanie zapobiegnie dywersyfikacji działań oraz wzmocni skuteczność nowego instrumentu. Rada Unii Europejskiej zaznacza jednak, że w tekście Decyzji powinna znajdować się dokładna definicja zwrotu „czynność dochodzeniowa” celem uniknięcia ewentualnych problemów interpretacyjnych ${ }^{12}$.

${ }^{9}$ Europejski nakaz dochodzeniowy odnosi się do czynności dochodzeniowych, co stanowi ogromny postęp w odniesieniu do europejskiego nakazu dowodowego, skupiającego się na ściśle określonych rodzajach dowodów: http://delegacionbruselas.cgae.es/portalBruselas/archivos/ficheros/1292945589 145.pdf, s. 2.

${ }^{10}$ Identyczne rozwiązanie przewidywała decyzja ramowa w sprawie europejskiego nakazu dowodowego.

11 Explanatory Memorandum, s. 5.

12 Opinia Rady Unii Europejskiej na temat dyrektywy w sprawie europejskiego nakazu dochodzeniowego, http://ec.europa.eu/justice/news/intro/doc/comment_2010_08_24_en.pdf, s. 11 (dostęp: 27.01.2012; dalej jako: Opinia); podobnie http://delegacionbruselas.cgae.es/portalBruselas/archivos/ ficheros/1292945589145.pdf, s. 4 (dostęp: 1.02.2012); D. Sayers, op. cit., s. 15. 
Decyzja nie określa w ścisły sposób organów uprawnionych do wydania nakazu. Zgodnie z art. 2 pkt a) lit i) oraz ii), będą to w szczególności: sędzia, sąd, sędzia śledczy, prokurator oraz inne, niewymienione w Decyzji organy śledcze, o ile zgodnie z prawem krajowym danego państwa są do tego uprawnione (np. organy policji, organy administracji publicznej $)^{13}$.

Europejski nakaz dochodzeniowy przedstawia się na formularzu dołączonym do projektu Decyzji (art. 5 ust. 1). Należy podkreślić, że nie istnieje inna forma wystąpienia o nakaz, aniżeli poprawnie uzupełniony i przekazany organowi wykonującemu formularz. Blankiet ten zawiera dane dotyczące między innymi:

- wskazania czynności dochodzeniowej, o którą wnosi organ wydający (wraz ze wskazaniem miejsca wykonania nakazu);

- tożsamości osób, których dotyczy dana czynność;

- organu wydającego nakaz (nazwa, adres, dane kontaktowe, dokładne dane osoby wydającej nakaz wraz ze wskazaniem stanowiska służbowego oraz nazwy urzędowej);

- rodzaj postępowania, w ramach którego wydawany jest nakaz;

- powód wydania nakazu (okoliczności przestępstwa, charakter i kwalifikacja prawna przestępstwa);

- wnioskowany termin wykonania nakazu ${ }^{14}$.

Nakaz sporządza się w języku (lub jednym z języków) urzędowych państwa wydającego bądź w jednym ze wskazanych przez dane państwo urzędowych języków Unii (art. 5 ust. 2).

Organ wydający nakaz przekazuje go bezpośrednio organowi wykonującemu w sposób zapewniający stwierdzenie jego autentyczności (art. 6 ust. 1). Przekazanie może się również odbyć za pośrednictwem zabezpieczonego systemu telekomunikacyjnego Europejskiej Sieci Sądowej (art. 6 ust. 3). Portale internetowe Unii Europejskiej, jak Europejska Siec Sądowa czy Europejski Atlas Sądowy mogą się również okazać pomocne w sytuacji, gdy odnalezienie odpowiedniego organu wykonującego stwarza problemy w państwie wydającym. Zamieszczone na stronach wyszukiwarki w prosty sposób umożliwiaja odnalezienie właściwej w danej sprawie instytucji ${ }^{15}$.

Wszelkie kontakty między organami wydającym i wykonującym odbywaja się bezpośrednio między nimi, za pomoca jakiegokolwiek środka komunikacji (art. 6 ust. 1). Każde państwo członkowskie może również wyznaczyć organ centralny, którego zadaniem będzie pomoc właściwym organom, szczególnie $\mathrm{w}$ kwestiach urzędowo-administracyjnych (art. 6 ust. 2). W przypadku przekazania nakazu niewłaściwemu organowi organ ten z urzędu przekazuje nakaz organowi właściwemu, niezwłocznie informując o tym fakcie organ wydający (art. 6 ust. 5).

${ }^{13}$ Zakres podmiotowy został przyjęty w identycznej formie, jak w decyzji ramowej w sprawie europejskiego nakazu dowodowego. Warto nadmienić, iż rozwiązanie to już w przypadku tego nakazu komentowano pozytywnie, gdyż stanowiło uszczegółowienie w stosunku do ogólnego jedynie zakresu przedstawionego w Decyzji o freezingu.

${ }^{14}$ Załącznik A do Decyzji.

${ }^{15}$ Zob. http://www.ejn-crimjust.europa.eu/ejn/ejn_home.aspx (dostęp: 13.02.2012). 


\section{TRYB WYKONANIA EUROPEJSKIEGO NAKAZU DOCHODZENIOWEGO}

Organ, do którego wpłynął nakaz dochodzeniowy, bez dodatkowych formalności dokonuje uznania oraz przystępuje do jego wykonania (art. 8 ust. 1). Obowiązkiem organu wykonujacego jest niezwłoczne poinformowanie organu wydającego o otrzymaniu nakazu. Dokonuje tego, wypełniając formularz zawarty w załączniku B Decyzji, maksymalnie w ciagu tygodnia od dnia otrzymania nakazu (art. 15 ust. 1). W sytuacji gdy błędnie lub niekompletnie wypełniono formularz, organ wykonujacy natychmiast (dowolna metoda) kontaktuje się $\mathrm{z}$ organem wydającym celem jego uzupełnienia (art. 15 ust. 2 pkt a lit i).

Od momentu otrzymania nakaz traktuje się go identycznie jak instrument krajowy państwa wykonującego. Oznacza to, że jeżeli organ wykonujacy nie powołuje się na żadna $\mathrm{z}$ podstaw odmowy lub odroczenia uznania lub wykonania, zobowiązany jest uznać i wykonać nakaz równie szybko (w trybie priorytetowym), jak w analogicznej sprawie krajowej (art. 8 ust. 1). Decyzja przewiduje jednak maksymalne terminy, których państwo wykonujące jest zobowiazzane dochować:

a) decyzję co do uznania lub wykonania podejmuje się nie później niż $\mathrm{w}$ terminie 30 dni od otrzymania nakazu (art. 11 ust. 3),

b) przeprowadzenia wnioskowanej czynności dochodzeniowej dokonuje się nie później niż w terminie 90 dni od dnia uznania nakazu (art. 11 ust. 4).

W wypadku braku praktycznej możliwości dochowania powyższych terminów istnieje możliwość jego przedłużenia maksymalnie o 30 dni. Organ wykonujący informuje o tym fakcie organ wydający, podając przyczyny opóźnienia oraz szacunkowy okres potrzebny na podjęcie czynności (art. 11 ust. 5).

Organ wydający nie ma wyłączności w decydowaniu co do zastosowania konkretnej czynności dochodzeniowej. Państwo wykonujące ma bowiem prawo odstąpić od wskazanych w nakazie wytycznych i zastosować czynność dochodzeniową innego typu, gdy:

a) wskazana $\mathrm{w}$ nakazie czynność dochodzeniowa nie istnieje $\mathrm{w}$ prawie państwa wykonującego (art. 9 ust. 1 pkt a),

b) użycie wskazanej w nakazie czynności dochodzeniowej jest możliwa wyłącznie w odniesieniu do danego charakteru bądź listy przestępstw i nakaz dochodzeniowy nie odnosi się do tych kategorii (art. 9 ust. 1 pkt b),

c) istnieje czynność dochodzeniowa wymagająca użycia łagodniejszych środków przymusu niż czynność wskazana w nakazie, gwarantująca jednocześnie taki sam rezultat (art. 9 ust. 1 pkt c). O propozycji zmiany czynności dochodzeniowej należy natychmiast powiadomić organ wydający (art. 9 ust. 2).

Ogromnym osiągnięciem twórców propozycji decyzji jest ograniczenie podstaw odmowy uznania lub wykonania nakazu. Poprzednie instrumenty przewidywały zawężony katalog podstaw odmowy, lecz w praktyce ich zakres okazywał się bardzo szeroki ${ }^{16}$. Uchylenie się od wykonania europejskiego

${ }^{16}$ Explanatory Memorandum, s. 11. 
nakazu dochodzeniowego będzie natomiast możliwe tylko w ściśle przewidzianych w decyzji wypadkach:

a) jeśli prawo państwa wykonującego przewiduje immunitet lub przywilej, który uniemożliwia wykonanie nakazu (art. 10 ust. 1 pkt a),

b) jeśli wykonanie nakazu może naruszać ochronę interesu publicznego (art. 10 ust. 1 pkt b),

c) jeśli wskazana w nakazie czynność dochodzeniowa nie istnieje w prawie państwa wykonującego lub jej zastosowanie jest możliwe jedynie w odniesieniu do danego charakteru bądź listy przestępstw, natomiast nakaz nie odnosi się do tych przestępstw oraz nie istnieje inna czynność dochodzeniowa umożliwiająca osiągnięcie tego samego rezultatu (art. 10 ust. 1 pkt c),

d) jeśli wydanie nakazu $\mathrm{w}$ analogicznej sprawie $\mathrm{w}$ państwie wydającym byłoby niemożliwe zgodnie z prawem tego państwa (art. 10 ust. 1 pkt d).

Rada Unii Europejskiej słusznie zwraca uwage na brak elementarnej podstawy odmowy - naruszenia zasady ne bis in idem ${ }^{17}$, stanowiącej jedna z kluczowych zasad współpracy w zakresie pozyskiwania dowodów w Unii Europejskiej ${ }^{18}$. Nie ulega wątpliwości, że w ostatecznej wersji Decyzji brak ten powinien zostać uzupełniony.

Organ wykonujący, zanim postanowi o odmowie uznania lub wykonania, kontaktuje się $\mathrm{z}$ organem wydającym celem zasięgnięcia opinii oraz ewentualnego uzupełnienia brakujących informacji (art. 10 ust. 2).

Również prawo do odroczenia wykonania nakazu zostało ograniczone i jest możliwe tylko, wtedy gdy:

a) może ono zaszkodzić toczącemu się w państwie wykonującym postępowaniu karnemu. $\mathrm{W}$ takim przypadku organ wykonujący wskazuje stosowny według swojego uznania okres odroczenia (art. 14 ust. 1 pkt a),

b) dowody, których dotyczy nakaz, sa już wykorzystywane w innym postępowaniu. Odroczenie trwać może dopóki, dopóty dowody te nie przestaną być w nim potrzebne (art. 14 ust. 1 pkt b).

Dowolna metoda pozwalająca uzyskać pisemne potwierdzenie organ wykonujący zobowiązany jest poinformować o odroczeniu wraz z podaniem informacji o jego przyczynie oraz o spodziewanym okresie oczekiwania (art. 15 ust. 2, lit b pkt ii).

Organ wykonujący jest zobowiazany natychmiast po ustapieniu podstaw odroczenia wykonać nakaz, informując o tym fakcie organ wydający (art. 14 ust. 2). Należy zaznaczyć, że $\mathrm{w}$ decyzji brakuje informacji o organach uprawnionych do wydania decyzji co do odmowy wykonania nakazu lub jego odroczenia ${ }^{19}$.

${ }^{17} \mathrm{Ne}$ bis in idem oznacza, że istnienie decyzji wydanej w jednym państwie członkowskim stanowi przeszkodę ponownego karania za ten czyn w pozostałych państwach członkowskich.

18 Opinia, s. 16.

${ }^{19} \mathrm{~W}$ decyzji ramowej w sprawie freezingu posługiwano się zwrotem ,właściwy organ sądowy państwa wykonującego", natomiast w decyzji ramowej w sprawie europejskiego nakazu dowodowego jako organy kompetentne w tej sprawie wskazano: sędziego, sędziego śledczego, prokuratora bądź inny organ, o ile uzyskał zatwierdzenie na odmowę wykonania lub odroczenie jednego z wcześniej wymienionych organów. 


\section{SZCZEGÓŁOWE PRZEPISY DOTYCZĄCE NIEKTÓRYCH CZYNNOŚCI DOCHODZENIOWYCH}

Oprócz ogólnego mechanizmu współpracy, w rozdziale IV Decyzji zawarto również szczegółowe przepisy co do przeprowadzania konkretnych czynności dochodzeniowych. Umiejscowienie w projekcie Decyzji dodatkowych wytycznych jest nowością w instrumentach współpracy opartych na wzajemnym uznawaniu $^{20}$. Szczegółowe przedstawienie pewnych czynności uznano za konieczne, gdyż ogólne zasady postępowania mogą się okazać niewystarczające w stosunku do szczególnego charakteru niektórych czynności. Co więcej, omawiane przepisy przewiduja dodatkowe podstawy odmowy wykonania nakazu $^{21}$. Rada Unii Europejskiej zaznacza jednak, że ze względu na wyjątkowy charakter niniejszych przepisów, głównie ich wpływ na zachowanie podstawowych gwarancji procesowych i przestrzeganie praw człowieka, rozdział ten ma jedynie charakter wstępny i wymagać będzie dalszych ustaleń. Również poszczególne państwa członkowskie uprawnione są do wystosowania własnych postulatów w tym zakresie ${ }^{22}$.

\section{Tymczasowe przekazanie osób pozbawionych wolności państwu wydającemu do celów dochodzeniowych}

Artykuł 19 Decyzji odnosi się do sytuacji, gdy organ wydajacy zwraca się do organu wykonującego o tymczasowe przekazanie osoby pozbawionej wolności $\mathrm{w}$ państwie wykonujacym ${ }^{23}$. Celem przekazania jest wykonanie czynności dochodzeniowej na terenie państwa wydającego, podczas której obecność danej osoby jest niezbędna. Natomiast warunkiem przekazania jest odesłanie tejże osoby w terminie określonym przez państwo wykonujące (art. 19 ust. 1). Czas aresztu tymczasowego na terytorium państwa wydającego wlicza się na poczet okresu pozbawienia wolności, któremu przekazywana osoba jest zobowiązana poddać się na terytorium państwa wykonującego (art. 19 ust. 6). Koszt takiego przekazania ponosi państwo wydające (art. 19 ust. 9).

Rozwiązaniem szczególnym w odniesieniu do ogólnego mechanizmu współpracy jest wprowadzenie dodatkowych podstaw odmowy. Oprócz powołania się na jedną z przewidzianych w art. 10 Decyzji, istnieje możliwość odmowy wykonania nakazu, gdy:

a) osoba pozbawiona wolności nie wyraża zgody na przekazanie,

b) przekazanie może skutkować przedłużeniem okresu pozbawienia wolności (art. 19 ust. 2).

${ }^{20}$ Zarówno Decyzja o freezingu, jak i o europejskim nakazie dowodowym przewidywały jedynie ogólny mechanizm współpracy.

${ }^{21}$ Explanatory Memorandum, s. 17.

22 Opinia, s. 23-24.

${ }^{23}$ Powyższe rozwiązanie wzorowane jest na art. 11 Europejskiej konwencji o pomocy prawnej w sprawach karnych z 1959 r.: http://conventions.coe.int/Treaty/EN/Treaties/PDF/Polish/030Polish.pdf (dostęp: 20.02.2012). 
Rada Unii Europejskiej proponuje kolejna podstawę odmowy - podejrzenie, że osoba przekazywana może paść ofiarą niehumanitarnego bądź poniżającego traktowania ${ }^{24}$. Biorąc jednak pod uwagę fakt, że nakaz dotyczy postępowania toczącego się na terenie UE, gdzie poszanowanie podstawowych zasad humanitaryzmu jest oczywiste, podstawa ta wydaje się zbędna.

\section{Tymczasowe przekazanie osób pozbawionych wolności państwu wykonujacemu do celów dochodzeniowych}

Artykuł 20 Decyzji podobnie jak artykuł poprzedzający odnosi się do przekazania osoby pozbawionej wolności, $\mathrm{z}$ tą różnicą, że tym razem czynność dochodzeniowa ma miejsce na terenie państwa wykonującego, a osoba pozbawiona wolności przebywa na terenie państwa wydającego ${ }^{25}$. Taki transfer może być potrzebny na przykład przy doprowadzeniu osoby podejrzanej na miejsce zbrodni (gdy przestępstwo zostało popełnione w państwie wykonującym) ${ }^{26}$. Koszty takiego przekazania ponosi państwo wydające, z wyjątkiem kosztów związanych $\mathrm{z}$ utrzymywaniem danej osoby $\mathrm{w}$ stanie pozbawienia wolności w państwie wykonującym (art. 20 ust. 6). Szczegółowe podstawy odmowy, przewidziane $\mathrm{w}$ art. 20 ust. 2 , to:

a) brak zgody danej osoby na jej przekazanie,

b) brak porozumienia między organami wydającym i wykonującym co do przekazania.

\section{Przesłuchanie wideokonferencyjne}

Współczesna technika oferuje wiele narzędzi pozwalających na szybkie i tanie komunikowanie się bez względu na odległość. Nie ulega wątpliwości, że organy wymiaru sprawiedliwości powinny $\mathrm{w}$ pełni korzystać $\mathrm{z}$ istniejących rozwiązań, zwłaszcza w przypadku postępowań transgranicznych, gdzie przeszkody terytorialne są zjawiskiem powszechnym. Szczególną rolę wśród dostępnych narzędzi odgrywa wideokonferencja stosowana głównie w postępowaniu dowodowym. Wideokonferencja umożliwia przesłuchania osób, których osobiste stawiennictwo w sądzie jest niemożliwe, na przykład świadków wymagających specjalnego traktowania, świadków zastraszonych, osób chorych czy przebywających w znacznej odległości od siedziby sądu, w którym odbywa się rozprawa. Jest to metoda niezwykle skuteczna, w dużej mierze ułatwiająca postępowanie oraz dodatkowo zapewniająca znaczną redukcję kosztów ${ }^{27}$.

Artykuł 21 Decyzji przewiduje szczegółowe informacje co do warunków wydania europejskiego nakazu dochodzeniowego $\mathrm{w}$ celu przesłuchania $\mathrm{w}$ formie

\footnotetext{
${ }^{24}$ Opinia, s. 23.

${ }^{25}$ Powyższe rozwiązanie wzorowane jest na art. 9 Europejskiej konwencji o pomocy prawnej w sprawach karnych pomiędzy państwami członkowskimi Unii Europejskiej, http://www.lex.pl/duakt/-/akt/dz-u-07-135-950 (20.02.2012).

${ }^{26}$ Explanatory Memorandum, s. 18.

${ }^{27}$ Sekretariat Generalny Rady Europejskiej, Wideokonferencje jako element europejskiego e-prawa. Zasady przeprowadzania wideokonferencji podczas transgranicznego postepowania sadowego, Bruksela 2009, https://e-justice.europa.eu/attachments/vc_booklet_pl.pdf (dostęp: 20.02.2012).
} 
wideokonferencji. Przesłuchanie na odległość jest dopuszczalne, gdy nie jest pożądane lub możliwe, by dana osoba stawiła się osobiście na terytorium państwa wydającego nakaz (art. 21 ust. 1), wraz ze wskazaniem dokładnej tegoż przyczyny (art. 21 ust. 5).

Przesłuchanie metodą wideokonferencji jest możliwe w odniesieniu do:

a) świadków,

b) biegłych,

c) oskarżonego.

Dopuszczalność przesłuchania oskarżonego wymaga dodatkowego komentarza. Warto nadmienić, że rozwiązanie to przewiduje również art. 10 ust. 9 Konwencji o pomocy prawnej w sprawach karnych pomiędzy państwami członkowskimi Unii Europejskiej z wyraźnym zastrzeżeniem, iż poszczególne państwa mogą oświadczyć, że nie będą z omawianego rozwiązania korzystaćéc ${ }^{28}$. $\mathrm{W}$ Polsce, zgodnie $\mathrm{z}$ art. $177 \S$ 1a k.p.k., przesłuchanie na odległość jest dopuszczalne wyłącznie $\mathrm{w}$ odniesieniu do świadka, a także odpowiednio do biegłego (art. 197 § 3 k.p.k. w zw. z art. 177 § 1a k.p.k.) i tłumacza (art. 204 $\S 3$ k.p.k. w zw. $\mathrm{z}$ art. 197 § 3 k.p.k. w zw. z art. 177 § 1a k.p.k.). Nie istnieją przepisy umożliwiające przesłuchanie metodą wideokonferencji oskarżonego, również w odniesieniu do wspomnianej Konwencji Polska wystosowała oświadczenie o niedopuszczalności przesłuchania oskarżonego na odległośćc ${ }^{29}$. Należy podkreślić, że możliwość przesłuchania za pomoca wideokonferencji oskarżonego, przewidziana w decyzji o europejskim nakazie dochodzeniowym, ma charakter niewiążący, stanowi jedynie możliwość w przypadku porozumienia obu państw, ponadto poparta jest dodatkowymi podstawami odmowy ${ }^{30}$.

Przesłuchanie $\mathrm{w}$ formie wideokonferencji, będące efektem wykonania nakazu, wiąże się z przestrzeganiem następujących zasad:

a) przesłuchanie następuje $\mathrm{w}$ obecności organu sprawiedliwości państwa wykonującego, który odpowiedzialny jest za ustalenie tożsamości danej osoby oraz zachowanie podstawowych zasad prawa obowiąujących $\mathrm{w}$ państwie wykonującym. W razie konieczności podczas przesłuchania obecny jest również tłumacz (art. 21 ust. 6 pkt a);

b) w razie konieczności państwa wydające i wykonujące ustalają środki ochrony osoby przesłuchiwanej (art. 21 ust. 6 pkt b);

c) zgodnie ze swoim prawem krajowym organ wydający jest zobowiązany prowadzić przesłuchanie lub sprawować kontrolę nad jego tokiem (art. 21 ust. 6 pkt c);

d) państwo wykonujące jest zobowiązane zapewnić obecność tłumacza ustnego na wniosek osoby przesłuchiwanej lub państwa wydającego (art. 21 ust. 6 pkt d);

e) osoba przesłuchiwana ma prawo odmowy składania zeznań, jakie przysługuje jej na podstawie prawa obowiązującego w państwie wydającym lub wykonujacym (art. 21 ust 6 pkt e).

${ }^{28}$ Zob. http://www.lex.pl/du-akt/-/akt/dz-u-07-135-950 (dostęp: 20.02.2012).

${ }^{29}$ A. Lach, Udziat oskarżonego $w$ czynnościach procesowych $w$ drodze videokonferencji, „Prokuratura i Prawo" 2009, nr 9, s. 25-26.

${ }^{30}$ Explanatory Memorandum, s. 22. 
Po przesłuchaniu, organ wykonujący sporządza protokół, w którym zawiera datę i miejsce przesłuchania, tożsamość przesłuchanej osoby, tożsamość i funkcję wszystkich innych osób z państwa wykonującego uczestniczących w przesłuchaniu, wszelkie złożone przysięgi oraz warunki techniczne panujące podczas przesłuchania. Tak sporządzony protokół organ wykonujący przekazuje organowi wydającemu (art. 21 ust. 7).

Państwo wydające jest zobowiązane zwrócić państwu wykonującemu wszelkie koszty związane z wideopołączeniem, obecnością tłumaczy, podróżami świadków bądź biegłych (art. 21 ust. 8).

Podobnie jak w przypadku poprzednich, szczególnych czynności dochodzeniowych, również nakaz o przesłuchaniu wideokonferencyjnym zawiera dodatkowe podstawy odmowy gdy:

a) stosowanie wideokonferencji jest sprzeczne $\mathrm{z}$ podstawowymi zasadami prawa obowiązującego w państwie wykonującym (art. 21 ust. 2 pkt a);

b) państwo wykonujące nie dysponuje wideokonferencyjnym zapleczem technicznym (art. 21 ust. 2 pkt b);

c) w odniesieniu do przesłuchania oskarżonego:

- oskarżony nie wyraził zgody na przesłuchanie na odległość (art. 21 ust. 10 pkt a);

- przesłuchanie taką metodą jest sprzeczne z prawem obowiązującym w państwie wykonującym (art. 21 ust. 10 pkt b).

Warto nadmienić, że wśród podstaw odmowy nie widnieje brak zgody ze strony świadka lub biegłego. Oznacza to, że to w gestii organów wymiaru sprawiedliwości leży ocena konieczności obowiązkowego stawiennictwa danej osoby na sali sądowej lub dopuszczalność zeznawania na odległość.

\section{Przesłuchanie telekonferencyjne}

Przesłuchanie w formie telekonferencji jest kolejnym sposobem wykorzystywania osiaggnięć techniki w postępowaniu transgranicznym. Aczkolwiek taka forma przesłuchania wydaje się skuteczniejsza w praktyce (głównie ze względu na możliwość przekazu zarówno głosowego, jak i wizualnego), zastosowanie telekonferencji często może okazać się rozwiązaniem korzystniejszym, prostszym i bardziej ekonomicznym.

Przesłuchany w formie telekonferencji może zostać jedynie:

a) świadek,

b) biegły, którzy zgodzili się na taką formę przesłuchania.

Obowiązkiem państwa wydającego po otrzymaniu nakazu jest powiadomienie świadka lub biegłego o terminie i miejscu przesłuchania, zweryfikowanie jego tożsamości oraz odebranie stosownego oświadczenia, że przesłuchiwany zgadza się na telekonferencję (art. 22 ust. 4).

Do dodatkowych podstaw odmowy zalicza się:

a) sprzeczność przesłuchania za pomocą telekonferencji z podstawowymi zasadami prawa obowiązującego w państwie wykonującym (art. 22 ust. 2 pkt a),

b) brak zgody świadka lub biegłego na przesłuchanie w formie telekonferencji (art. 22 ust. 2 pkt b). 


\section{Informacje o rachunkach bankowych, transakcjach bankowych oraz monitorowanie transakcji bankowych}

Szczegółowe informacje dotyczące rachunków bankowych są niezwykle ważne przy ustalaniu korzyści majątkowych pochodzących $\mathrm{z}$ przestępstw. Swobodny przepływ kapitału w Unii Europejskiej sprzyja bowiem ,,przerzucaniu" oraz ukrywaniu majątku zdobywanego w sposób nielegalny. Z pewnością rozwiązania zawarte w Decyzji usprawnią ujawnianie i zajmowanie dochodów pochodzących z działalności przestępczej.

Europejski nakaz dochodzeniowy można wydać w celu ustalenia, czy dana osoba (zarówno fizyczna, jak i prawna), co do której toczy się postępowanie karne, kontroluje jakikolwiek rachunek bankowy w państwie wykonującym (art. 23 ust. 1). W treści nakazu należy wskazać, dlaczego żądane informacje mogą mieć znaczenie w toczącym się postępowaniu, na jakiej podstawie zakłada się istnienie takowych rachunków oraz - jeżeli to możliwe - wskazanie, które banki je prowadzą (art. 23 ust. 6).

Za pomocą nakazu, można również wnioskować o:

a) udostępnienie informacji o transakcjach bankowych dokonanych za pośrednictwem rachunków bankowych wskazanych w nakazie (art. 24),

b) monitorowanie operacji bankowych na wskazanych rachunkach bankowych i we wskazanym czasie (art. 25).

\section{ZAGROŻENIA ZWIAZZANE Z EUROPEJSKIM NAKAZEM DOCHODZENIOWYM}

Europejski nakaz dochodzeniowy, ze względu na daleko idące uprawnienia organów ścigania oraz wąskie podstawy odmowy, oprócz zagorzałych zwolenników, zyskał sobie również szerokie grono krytyków. Szczególnie nieprzychylni nowym rozwiązaniom są obrońcy praw człowieka, którzy podnoszą, że stosowanie nakazu w istotny sposób naruszać może:

1. Prawo do obrony, będące jedną z podstawowych zasad procesu karnego. Wydanie nakazu może naruszać domniemanie niewinności oraz znacznie ograniczać prawo do obrony. Nakaz nie przewiduje bowiem żadnych gwarancji obejmujących oskarżonego - w szczególności dotyczących darmowego dostępu do tłumacza oraz obrońcy, co w praktyce może uniemożliwiać skuteczną obronę osoby oskarżonej w procesie międzynarodowym.

2. Prawo do rzetelnego procesu w przypadku, gdy dowody wykorzystywane $\mathrm{w}$ procesie toczącym się $\mathrm{w}$ danym państwie moga być gromadzone zgodnie $\mathrm{z}$ procedurami obcego państwa. Ponadto w Decyzji brakuje zasady ne bis in idem, jako podstawy odmowy wykonania nakazu, co skutkować może podwójnym karaniem za to samo przestępstwo ${ }^{31}$.

${ }^{31}$ Opinion of the European Union Agency for Fundamental Rights on the draft Directive regarding the European Investigation Order, http://fra.europa.eu/fraWebsite/research/opinions/op-eio_en.htm (dostęp: 1.03.2012). 
3. Istnieje również pogląd, że podejrzenie naruszenia praw człowieka powinno znaleźć się w podstawach odmowy wykonania nakazu. Decyzję w tej kwestii podejmowałby organ wykonujący ${ }^{32}$. Należy jednak zauważyć, że tak ogólny powód mógłby zbytnio prowokować organy wykonujące do odmowy wykonania nakazu.

Trudno również zgodzić się z zastrzeżeniem, że decyzja zawierać powinna dokładne rozdzielenie kompetencji sądów i prokuratur od działań policyjnych ${ }^{33}$. Należy zaakceptować fakt, że systemy prawne państw członkowskich Unii Europejskiej, choć moga się istotnie różnić, dają gwarancję rzetelnego i sprawiedliwego procesu. W związku z powyższym skuteczne ściganie karne w Europie jest możliwe jedynie, gdy organy ścigania będą obdarzały się wzajemnym zaufaniem. Oczywiście, odmienności procesowe mogą prowokować poważne problemy, na przykład co do dopuszczalności zdobytych dowodów w państwie wydającym. Taka sytuacja jest możliwa w przypadku, gdy prawodawstwa obu państw znacznie się od siebie różnią i przewidują rozbieżne metody zdobywania dowodów, na przykład jeśli w państwie wydającym przeszukania lokalu można dokonać tylko w ciągu dnia, natomiast w państwie wykonującym również w nocy. Zgodnie z art. 8 pkt 1 Decyzji organ wykonujący stosuje środki prawne przewidziane we własnym prawie, stąd w pełni akceptowane jest dokonanie przeszukania również w godzinach nocnych. Dopuszczalność tak zdobytych dowodów może być następnie kwestionowana w trakcie procesu $\mathrm{w}$ państwie wydającym ${ }^{34}$. Aby uniknąc podobnych problemów, organ wydajacy może wskazać organowi wykonującemu pewne procedury i formalności, jakie winny zostać dochowane w trakcie zdobywania dowodów. O ile nie sa one sprzeczne $\mathrm{z}$ podstawowymi zasadami państwa wykonującego, organ wydajacy ma obowiązek działania zgodnie $\mathrm{z}$ wytycznymi organu wydającego (art. 8 pkt 2). Ponadto organ wydający może również zażądać obecności organów państwa wydającego podczas wykonywania nakazu (art. 8 pkt 3).

\section{ZAKOŃCZENIE}

Idea stworzenia jednego, ogólnego instrumentu współpracy od dawna uważana była za jedyny sposób skutecznej kolaboracji w sprawach karnych $\mathrm{w} \mathrm{UE}^{35}$. Europejski nakaz dochodzeniowy, wprowadzając szereg zmian $\mathrm{w}$ stosunku do poprzednio obowiązujących instrumentów, stwarza ogromne szanse na ulepszenie europejskiego ścigania karnego ${ }^{36}$ oraz realizację idei pełnej współpracy sądowej w sprawach karnych w UE. Istnieje ogromna szansa, że nakaz, zastępując wiele poprzednich (i mało skutecznych) instrumentów, zapanuje nad chaosem proceduralnym, z jakim borykają się organy pragnące

${ }^{32}$ D. Sayers, op. cit., s. 16.

33 Ibidem, s. 17.

${ }^{34}$ Explanatory Memorandum, s. 8-9.

35 J. R. Spencer, op. cit., s. 479.

${ }^{36}$ S. Peers, Statewatch Analysis - Update The Proposed European Investigation Order, http://www.statewatch.org/analyses/no-112-eu-eio-update.pdf (dostęp: 1.03.2012). 
zdobyć dowody poza terenem własnego kraju. Natomiast wszelkie zagrożenia, jakie mogą wynikać ze stosowania nakazu, zależeć będą w dużej mierze od nastawienia oraz kultury procesowej organów wydających i wykonujących. Decyzja pozwala bowiem na swobodne komunikowanie się wspomnianych organów we wszystkich sprawach, co znacznie ułatwiać może wyjaśnianie nieporozumień oraz zapobieganie wszelkim uchybieniom.

Decyzja w sprawie europejskiego nakazu dochodzeniowego bez wątpienia jest instrumentem przełomowym, znoszącym wiele ograniczeń proceduralnych i stwarzającym realną możliwość usprawnienia europejskiego procesu karnego. Jedynie daleko idący instrument zapewni bowiem organom ścigania możliwość walki z przestępstwami o wymiarze transgranicznym.

mgr Martyna Kusak

Uniwersytet im. Adama Mickiewicza w Poznaniu

\section{EUROPEAN INVESTIGATION ORDER - A BREAKTHROUGH IN THE EUROPEAN CRIMINAL PROSECUTION?}

Summary

The paper presents the Proposal for a Directive of the European Parliament and the Council regarding the European Investigation Order (EIO) in criminal matters. It describes the essence of the new instrument and the procedure of how to move for it, as well as of its execution. The authoress compares the EIO with the existing EU instruments for cooperation in criminal matters, explaining its innovative nature in the field of cross-border criminal prosecution. The risks associated with the order have been identified, followed by some proposals of improvements of certain adopted solutions. 
